\title{
The Alfalfa (Medicago sativa) TDY1 Gene Encodes a Mitogen-Activated Protein Kinase Homolog
}

\author{
Mark A. Schoenbeck, ${ }^{1}$ Deborah A. Samac, ${ }^{2,5}$ Maria Fedorova, ${ }^{1}$ Robert G. Gregerson, ${ }^{3}$ \\ J. Stephen Gantt, ${ }^{4}$ and Carroll P. Vance ${ }^{1,5}$ \\ ${ }^{1}$ Department of Agronomy and Plant Genetics, and ${ }^{2}$ Department of Plant Pathology, University of Minne- \\ sota, St. Paul 55108, U.S.A.; ${ }^{3}$ Department of Biology, Lyon College, Batesville, AR 72503, U.S.A.; \\ ${ }^{4}$ Department of Plant Biology, University of Minnesota, St. Paul 55108, U.S.A.; ${ }^{5}$ US Department of \\ Agriculture, Agricultural Research Service, Plant Science Research Unit, St. Paul, MN 55108, U.S.A. \\ Accepted 30 June 1999.
}

\begin{abstract}
Development of root nodules, specifically induction of cortical cell division for nodule initiation, requires expression of specific genes in the host and microsymbiont. A fulllength cDNA clone and the corresponding genomic clone encoding a MAP (mitogen-activated protein) kinase homolog were isolated from alfalfa (Medicago sativa). The genomic clone, TDY1, encodes a 68.9-kDa protein with 47.7\% identity to MMK4, a previously characterized MAP kinase homolog from alfalfa. TDY1 is unique among the known plant MAP kinases, primarily due to a 230 amino acid C-terminal domain. The putative activation motif, Thr-Asp-Tyr (TDY), also differs from the previously reported Thr-Glu-Tyr (TEY) motif in plant MAP kinases. TDY1 messages were found predominantly in root nodules, roots, and root tips. Transgenic alfalfa and Medicago truncatula containing a chimeric gene consisting of $1.8 \mathrm{kbp}$ of $5^{\prime}$ flanking sequence of the TDY1 gene fused to the $\beta$-glucuronidase (GUS) coding sequence exhibited GUS expression primarily in the nodule parenchyma, meristem, and vascular bundles, root tips, and root vascular bundles. Stem internodes stained intensely in cortical parenchyma, cambial cells, and primary xylem. GUS activity was observed in leaf mesophyll surrounding areas of mechanical wounding and pathogen invasion. The promoter was also active in root tips and apical meristems of transgenic tobacco. Expression patterns suggest a possible role for TDY1 in initiation and development of nodules and roots, and in localized responses to wounding.
\end{abstract}

Additional keywords: lucerne, Nicotiana tabacum, phosphorylation, Sinorhizobium meliloti.

Mitogen-activated protein (MAP) kinases, also called extracellular signal-regulated kinases (ERKs), are a family of eu-

Corresponding author: Deborah A. Samac

E-mail: debbys@puccini.crl.umn.edu

Nucleotide and/or amino acid sequence data have been submitted to the GenBank data base as accession number AF129087.

This article is in the public domain and not copyrightable. It may be freely reprinted with customary crediting of the source. The American Phytopathological Society, 1999. karyotic, serine-threonine, protein kinases demonstrated to participate in the cascade of protein phosphorylations by which numerous and diverse signals are transduced within the cell (Ferrell 1996; Machida et al. 1997). Currently, five subfamilies of MAP kinaselike proteins are categorized by amino acid sequence similarity and by the nature of the regulatory motif, which is the site of activating phosphorylation (Ferrell 1996). Some members of the MAP kinase family have been shown to be activated by a MAP kinase cascade in which MAP kinase becomes phosphorylated by action of an upstream kinase (MAP kinase kinase) that is phosphorylated in turn by its own upstream kinase (MAP kinase kinase kinase). Activation of MAP kinase occurs by dual phosphorylation of specific threonine and tyrosine residues in region VIII in the kinase domain (Ferrell 1996).

cDNA clones encoding MAP kinase homologs have been isolated from several plant species including alfalfa (Duerr et al. 1993; Jonak et al. 1993; Bögre et al. 1999), Arabidopsis (Mizoguchi et al. 1993), and tobacco (Seo et al. 1995). In each of these species, multiple MAP kinase homologs were demonstrated to occur. All reported MAP kinase homologs in plants have a high degree of structural conservation and share 40 to $55 \%$ amino acid sequence identity with MAP kinases from other eukaryotes. To date, all reported plant MAP kinase homologs are members of the TEY subfamily of MAP kinases, named for the conserved Thr-Glu-Tyr (TEY) tripeptide activation site (Ferrell 1996). This similarity is probably a result of the homology-based cloning strategies employed. It is likely that a much wider range of homologs occurs in plants than has been demonstrated, considering the evidence for multiple signal transduction pathways in yeast and metazoans, and the number of specialized interactions with which plants are challenged.

In animal systems, MAP kinase cascades have been shown to be activated by extracellular stimuli that influence cell divisions and differentiation. Although no complete MAP kinaselike cascade has been characterized in plants, evidence suggests that MAP kinases have a similar role in plants as well. Transcripts of the alfalfa MAP kinase MMK1 are found at elevated levels in cultured alfalfa cells in the G2 phase of the cell cycle (Jonak et al. 1993). Another distinct alfalfa MAP kinase, MMK3, is highly expressed and active in young alfalfa leaves and flowers (Bögre et al. 1999). MMK3 activity is 
specific to metaphase cells and the protein is localized to cell midplanes and cell plates in late anaphase and telophase root tip cells (Bögre et al. 1999). Several studies have shown a correlation between the accumulation of mRNA or the activation of MAP kinase activity and diverse types of plant stress responses, including response to mechanical wounding (Seo et al. 1995; Bögre et al. 1997), drought and cold (Jonak et al. 1996), and fungal elicitors (Suzuki and Shinshi 1995; Ligterink et al. 1997). Other studies suggest roles for MAP kinases in mediating the effects of plant growth regulators such as abscisic acid (Knetsch et al. 1996) and auxin (Mizoguchi et al. 1994). Constitutive expression of MAP kinase homologs has also been detected in roots, leaves, stems, and flowers. Thus, expression of MAP kinase homologs in plants appears to occur in dividing cells but does not appear to be limited to cells undergoing mitosis.

In efforts to enhance our understanding of the genes and cellular processes involved in root nodule formation, we have cloned an alfalfa (lucerne; Medicago sativa) gene that encodes a distant relative of other reported plant MAP kinases. The objective of this work was to characterize the gene encoding this MAP kinase homolog, named TDY1, for the putative ThrAsp-Tyr (TDY) activation motif, and to describe its expression pattern by examining mRNA distribution and promoter$\beta$-glucuronidase (GUS) activity in transgenic alfalfa. Promoter expression patterns were also examined in transgenic Medicago truncatula, a diploid annual relative of alfalfa, and in tobacco (Nicotiana tabacum).

\section{RESULTS}

Cloning and molecular characterization of the TDY1 gene.

An 885-bp DNA fragment encoding a polypeptide similar to eukaryotic protein kinases was generated and cloned from a reverse-transcription polymerase chain reaction (RT-PCR) of alfalfa leaf poly $(\mathrm{A})^{+}$RNA. This fragment was used to screen an alfalfa root nodule cDNA library (Gregerson et al. 1993) for corresponding cDNAs. Three cDNA clones, mk1, mk6, and $\mathrm{mk} 8$, were recovered, ranging in length from 2.2 to 2.4 $\mathrm{kbp}$. Sequence analysis revealed the three clones share a high degree of nucleotide sequence identity. A radioactive probe generated from an internal SstI fragment of one cDNA clone (mk8) was used to screen an alfalfa genomic DNA library (Gregerson et al. 1994). A single recombinant phage $\lambda$ clone was recovered and subcloned as two overlapping fragments; an $S s t \mathrm{I}$ restriction fragment $(\mathrm{pS} 1)$ approximately $5 \mathrm{kbp}$ in length that hybridized with a probe generated from the $5^{\prime}$ end of the mk8 cDNA, and an EcoRI fragment (pG81) of approximately $5.3 \mathrm{kbp}$ that hybridized with probes from the middle and 3 ' end of the cDNA (Fig. 1). The clone pS1 was further subcloned as a 2-kbp HindIII-EcoRI fragment (pSIRID3). The $7.3 \mathrm{kbp}$ spanned by clones pG81 and pSIRID3 were sequenced with internal primers (GenBank accession no. AF129087).

Figure 1 shows the intron-exon structure of the TDY1 gene as determined by comparing the genomic sequence with the cDNA clones. In the longest cDNA, the putative translation initiation codon is preceded by 385 bp with stop codons in all frames. Between the predicted translational stop codon and the beginning of the cDNA poly(A) tract are $183 \mathrm{bp}$ of nontranslated sequence, including a motif (AATAAAAAA) matching the eukaryotic mRNA polyadenylation signal (Proudfoot 1991). Exons 1 through 6 and the 5' end of exon 7 have significant sequence similarity with other reported MAP kinase genes, while the remainder of exon 7 and exons 8 through 10 have similarity only to the partial sequence of a putative MAP kinaselike protein from Selaginella lepidophylla (resurrection plant), a seedless vascular plant (GenBank accession no. U96717). The 10 exons are interrupted by introns ranging in length from 111 to $899 \mathrm{bp}$. All nine introns begin and end with GT...AG dinucleotide boundaries; furthermore, introns 1 to 4 and 7 end with a conserved TGCAG motif, and introns 5 and 6 end with the variants TGTAG and CGCAG, respectively. Of interest, though not necessarily of consequence to regulation or function, is a $(\mathrm{T})_{29}$ tract within the seventh intron of the TDY1 gene.

To estimate the TDY1 gene copy number in alfalfa, restriction enzyme-digested genomic DNA from a single alfalfa plant was blotted and probed with an internal 1.6-kbp SstI fragment from cDNA mk8. Figure 2 shows multiple bands in

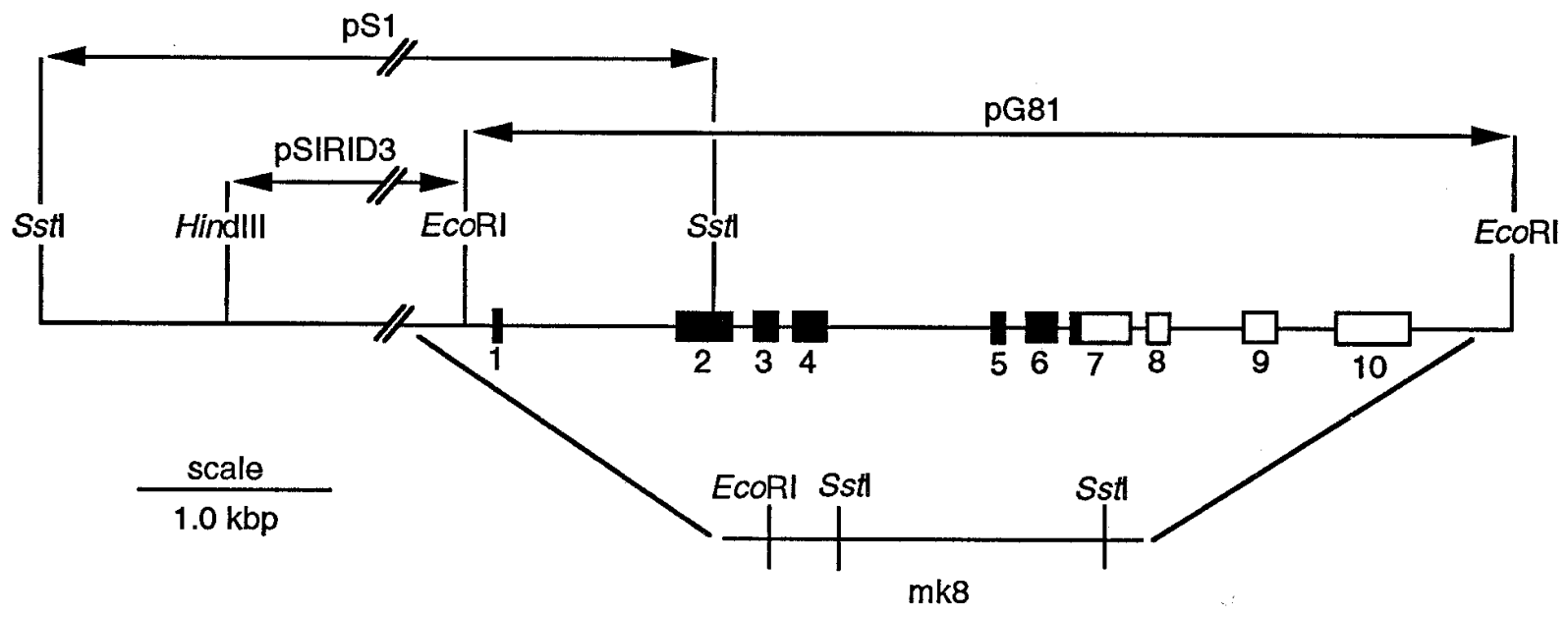

Fig. 1. Diagrammatic representation of the alfalfa $T D Y 1$ gene. Exons are indicated by boxes; introns and $5^{\prime}$ and $3^{\prime}$ nontranslated regions are represented by lines. Exons with significant homology to other reported mitogen-activated protein (MAP) kinases are filled in black; open exons have significant similarity only to the predicted Selaginella lepidophylla MAP kinase homolog. Below the diagram of TDY1 is a partial restriction map for cDNA mk8. 
each lane following prolonged high-stringency washes, suggesting that $T D Y 1$ is present as multiple alleles or as a small gene family in alfalfa. Because alfalfa is an autotetraploid, and because restriction patterns differed slightly between the cloned cDNAs, it is likely that the darker bands represent alleles defined by different restriction sites inside or outside the gene. The multiple faint bands also visible may be related kinase genes.

\section{The predicted TDY1 protein.}

The TDY1 gene encodes a polypeptide 608 amino acids in length with a molecular mass of $68.9 \mathrm{kDa}$, making the TDY1 protein significantly larger than other MAP kinases characterized in plants. Figure 3 shows the similarity between the predicted TDY1 protein and MAP kinases from the slime mold Dictyostelium discoideum (Gaskins et al. 1994), the yeast Saccharomyces cerevisiae FUS3 (Elion et al. 1990), and the stress-activated alfalfa MMK4 (Jonak et al. 1996). FASTA analysis, to calculate the highest similarity scores of overlapping sequences, found TDY1 to be 48.1, 47.7, and $43.6 \%$ identical to $D$. discoideum ERK1, alfalfa MMK4, and S. cerevisiae FUS3, respectively. The TDY1 protein includes the 11

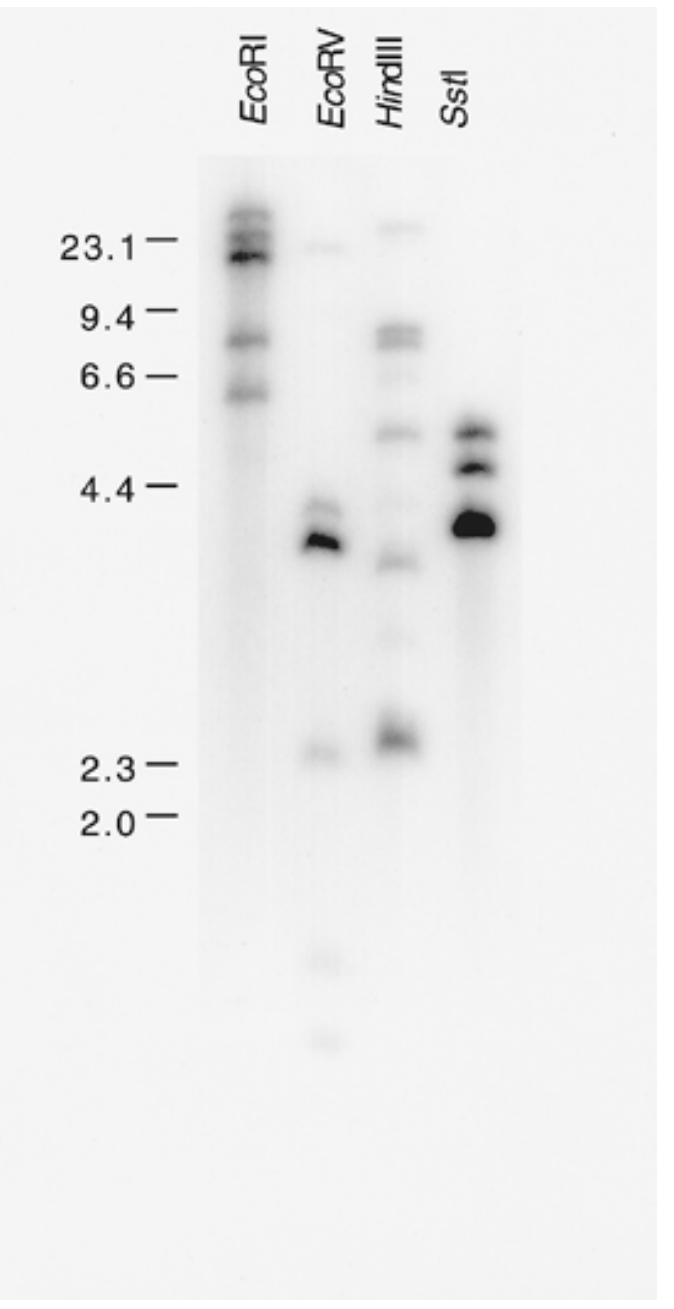

Fig. 2. Genomic DNA blot analysis of the TDY1 gene. Genomic DNA from a single alfalfa plant ( $20 \mu \mathrm{g}$ per lane) was digested, blotted, and probed with a 1.6-kbp SstI fragment from cDNA mk8. subdomains conserved among eukaryotic serine-threonine protein kinases (Hanks and Hunter 1995). TDY1 differs from other plant MAP kinases in that the regulatory Thr-x-Tyr tripeptide adjacent to the kinase domain (subdomain VIII) occurs as Thr-Asp-Tyr, in contrast to the common Thr-Glu-Tyr tripeptide. A data base search with the C-terminal 246 amino acids resulted in only one significant match to the partial sequence of a predicted MAP kinase-homolog from Selaginella lepidophylla (GenBank accession no. U96717). Analysis of potential tertiary structure with the NNPREDICT program (Kneller et al. 1990) suggests that the final 42 residues of the C-terminal end of the predicted TDY1 protein could form an $\alpha$-helix. Analysis of this same region with the TMpred program (Hofman and Stoffel 1993), which predicts potential transmembrane motifs, finds that a portion of the predicted $\alpha$ helix might be a membrane-spanning region.

Because the similarity of the predicted TDY1 protein to other families of MAP kinases could potentially reveal something of its function, and to further characterize its relatedness to other MAP kinases, we constructed a phylogenetic tree, shown in Figure 4, of TDY1 and reported MAP kinases from plants, fungi, protists, and metazoans representing all known MAP kinase subfamilies. Prior to a heuristic tree search with the Phylogenetic Analysis Using Parsimony (PAUP) program (D. L. Swofford, Illinois Natural History Survey, Champaign, IL), the 36 submitted sequences were aligned with the CLUSTAL W 1.7 alignment program (Thompson et al. 1994) and trimmed to remove unique features at the amino- and carboxyl-terminal ends as shown in Figure 3. Internal gaps were not removed. With this alignment, all previously reported MAP kinases from plants cluster in two distinct groups apart from MAP kinases from fungi, animals, and protists. TDY1 forms a separate clade from the other three groups and has no close relatives.

\section{TDY1 RNA message.}

Initial experiments in which blots of poly $(\mathrm{A})^{+} \mathrm{RNA}$ from alfalfa leaves, cotyledons, stems, roots, and root nodules were probed with the TDY1 cDNA clone suggested that the RNA message was enhanced specifically in nodules (data not shown). Because alfalfa root nodules possess an indeterminate meristem, it was possible that the message was enhanced by the larger fraction of dividing cells in this organ. To test the possibility that TDY1 mRNA is associated primarily with dividing cells, blots were made with poly $(\mathrm{A})^{+} \mathrm{RNA}$ from alfalfa shoot apices, stem internodes, leaves, cotyledons, root nodules, root tips, and roots from which the tips had been removed. Root tips were judged to be the first 3 to $5 \mathrm{~mm}$ of root. When blots were probed with the internal 1.6-kbp SstI fragment from cDNA mk8, a single band was observed in each lane at approximately $2.4 \mathrm{kbp}$ (Fig. 5), corresponding with the size of the cDNAs and predicted coding region of the gene. The same blot stripped and hybridized with a probe from the 3' noncoding region yielded the same result, indicating that the signal was likely not the result of crosshybridization with similar transcripts from different genes (data not shown). The TDY1 message was highest in root nodules, with high levels of message in roots without tips, root tips, leaves, and shoot apices, in descending order. Message was also present in stems and cotyledons, but was less than a third of that occurring in nodules, as determined by radioana- 
lytic detection. Equal loading of poly(A) ${ }^{+}$RNA in each lane was verified by re-probing the stripped membrane with ${ }^{32} \mathrm{P}$ labeled poly $(\mathrm{U})$ oligomers.

\section{The putative TDY1 promoter and expression of TDY1- GUS fusions in transgenic alfalfa, M. truncatula, and tobacco.}

In addition to the entire genomic region corresponding to the cDNA clones, an additional $1.8 \mathrm{kbp} 5^{\prime}$ to the transcribed region was cloned and sequenced. This DNA sequence, illustrated in Figure 6, was searched for known cis-acting elements that may participate in the function of the TDY1 promoter. As the transcriptional start has not been mapped, the positions reported here are relative to the putative translational start codon. No genuine match to the TATAAA motif, common in eukaryotic promoters (Maniatis et al. 1987) occurs upstream from the longest cDNA, though a $\mathrm{T}(\mathrm{A})_{8}$ sequence occurs just 13 bases prior to the beginning of the longest cDNA. A CAAT sequence occurs at position -430 ( 45 bases before the cDNA), relative to the ATG of the open reading frame, and another at position -595. TATA- and CAAT-like motifs also occur within the $5^{\prime}$ nontranslated region of the longest cDNA, but before the beginning of two shorter cDNAs, possibly indicating a second transcriptional start site. Some unique elements are found within this $1.8-\mathrm{kbp} 5^{\prime}$ flanking region. The AAAGAT sequence, which is conserved among soybean leghemoglobin gene promoters (Stougaard et al. 1987), occurs at positions $-1468,-642$, and -505 . Tandem and inverted DNA repeated sequences have been demonstrated to contribute to the function of plant promoters, including nodule-enhanced genes (Jørgensen et al. 1991). The REPEAT search function of the Genetics Computer Group (GCG) software package located a pair of tandem 19-base direct repeats, CTGAT(A/G)(G/A)
CTTATAGCTGAT, beginning at positions -1853 and -1831 , respectively. These repeats are flanked by, and partially overlapping with, a pair of 15-base repeats, ATAGCTGATAAG CTA, at positions -1869 and -1822 . A STEMLOOP program search, which locates inverted repeats, found an 18-base inverted repeat, ATAGCTTATAAGCTCGTT, at positions -1005 and -922 . Within the putative $5^{\prime}$ nontranslated region of the cDNA is a polypyrimidine stretch, $\mathrm{C}(\mathrm{CT})_{2} \mathrm{~T}(\mathrm{CT})_{9}$, beginning at position -230 . The $(\mathrm{CT})_{9}$ portion of this polypyrimidine stretch is also found in the $5^{\prime}$ nontranslated region of the $M M K 2$ cDNA, a previously characterized alfalfa MAP kinase homolog (Jonak et al. 1995).

To examine further the pattern of TDY1 expression in different organs, $1.8 \mathrm{kbp}$ of the $5^{\prime}$ flanking region, encompassing the putative TDY1 promoter, was fused to the GUS reporter gene. A transcriptional fusion construct (pB120) included 182 bases of the $5^{\prime}$ untranslated region, with translation beginning at the GUS start codon, while the translational fusion (pB125) included the entire $5^{\prime}$ untranslated region and TDY1 amino acids up to the seventh residue (Fig. 6). These constructs were introduced to alfalfa via Agrobacterium tumefaciens and 15 independent transgenic plants were regenerated with each construct. Approximately two-thirds of the plants expressing either the transcriptional or translational fusions had similar patterns of GUS expression although plants containing the transcriptional fusion stained less intensely in every instance. Staining was monitored closely and stopped after $1 \mathrm{~h}$ or less to limit diffusion of the blue product. GUS activity was observed in root tips, nodules, leaf and stem vascular tissues, and glandular trichomes. Root and nodule primordia stained intensely and were clearly distinguishable prior to emergence from the root cortex (Fig. 7A). In primary (Fig. 7B) and secondary roots, most staining occurred at the tips, although staining was

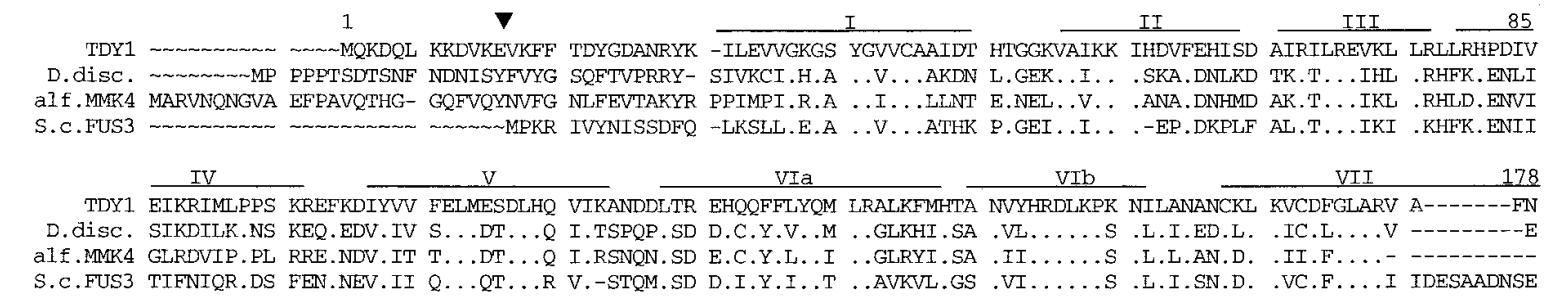

S.C.FUS3 TIFNIOR.DS FEN.NEV.II Q ...QT ...R V.-STOM.SD D.I.Y.I..T ..AVKVL.GS .VI....S .I.I.SN.D. .VC.F...I IDESAADNSE

TDY1 TTETTTFWID YVATRWYRAP ELCGSFFAKY TPAIDIWSIG CIFAEVLTGK PLFPGKSIVH QLDLITDLLG TPPPEI-ISG VRNEKARKYL MEMRKKL--P D.diSC. DATHQGFM.E ... . . . . . . VILS-WNK. TK.I.I..V. ..FA.LLGRK .L.Q.KDYI. .IT. IIETI. S. -SEEDICN IANEQ..QFI RSLNMGNQPK aIf.MMK4 PTMESDFM.E ..V. . . . . . .LLLN-SSD. TS.I.V.V. ..FM.LMNKK .L.P.KDHV. .MR. LTELL. T. -TDADVGL VKMDD. .RYI RQL--PQYPR S.C.FUS3 PTGQQSGM.E ..A...... .VMLT-SAK. SR.M.V..C. ..LA.LFLRR .I.P.RDYR. .LL.IFGII. T.HSDNDLRC IESPR..EYI KSL- -PMYPA TDY1 VPFERKFPNA DPL_ALRLLQR ILAFDPKDRP TAQFALAADPF FKGLAKIERE PSSQPI--SR MEFDFERRRV SKDDIKELIY REILEYHPQL LKDYYSGTEG D.disC. VNEANM. .KA N.DAID.LER MLYF..SK.L .VE...AH.Y FQSLHDPSD- -..E. .CLHK FSLNFEAWDL NRDLL.EL.Y N.MLAYYHPED PQAFYYTDLN alf.MMK4 QPLINRV. .HV H.LAID.VDK MLTI. .TR. I .VE. . AH.Y LEKLHDVAD- ---E. .CMEP FSFEFEQQHL DEEQT. EM.Y R.ALAINNEEY A S.C.FUS3 APLEKM..RV N.KGID.LQR MLVF..AK.I .AK...EH.Y LQTYHDPNDE PEGE. .PPSF FEFDHYKEAL TTKDL.KL.W N.IFS

TDY1 TUEY 473 D. đISC. NPNFINLSRIQ SSSELFNLLQ QQKQPIHQQV NQQSIKINN

TDY1 VTGPVLYDNG RSTKDNYDAR IFYQNAIPQA ISPHCFQRVA NAHQTSTKTT PETYKDNSQG KHQLSPKKCN VPARFAFDLN TNPYHQQSKN DLLNDPVIVI 608

TDY1 DAKLLKAQSQ FGAAGAAAVA VAAHRHSAGF QYGLT

Fig. 3. The predicted TDY1 protein and alignment with other mitogen-activated protein (MAP) kinase homologs. The TDY1 protein includes the 11 conserved subdomains found in most eukaryotic protein-serine kinases (overlined, with Roman numerals). The divergent Asp within the putative regulatory tripeptide is indicated with a star. In the alignment of TDY1 with Dictyostelium discoideum (D. disc.) ERK1, alfalfa MMK4 (alf. MMK4), and Saccharomyces cerevisiae FUS3 (S. c. FUS3), gaps are indicated by hyphens, and invariant amino acids are represented by periods. Arrowheads at Val ${ }_{13}$ and $\mathrm{Glu}_{358}$ indicate the bounds of the region used for the phylogenetic analysis in Figure 4. 
also observed in the vascular tissues of young roots and intermittently in the cortex of older roots. In young nodules (Fig. 7C), staining occurred throughout the nodule with the meristem staining most intensely. Within the mature nodule, the darkest staining occurred at the meristem and nodule parenchyma (Fig. 7D) with less staining of the cells in the infected symbiotic zone, and staining in senescent regions was limited to vascular bundles. In sections of young stem internodes (Fig. 7E) staining occurred in the chlorenchyma, the cambium, and the primary xylem. The procumbent multicellular glandular trichomes on stems and stipules stained intensely while the single-celled, elongated trichomes on stems and leaves did not stain. Constitutive expression in leaves was limited to vascular tissues. However, $24 \mathrm{~h}$ after mechanical wounding, staining was observed in mesophyll surrounding the wounded cells. Similarly, mesophyll immediately surrounding infection sites caused by the fungal pathogen Phoma medicaginis also stained positively for GUS (Fig. 7G).

To investigate the expression pattern of the TDY1-GUS gene in heterologous plant species, the pB125 construct was introduced into $M$. truncatula and tobacco. GUS activity was visualized by 5-bromo-4-chloro-3-indolyl- $\beta$-D-glucuronic acid (X-gluc) staining of the original transformed plants $\left(\mathrm{T}_{0}\right)$ and in plants grown from seed of $\mathrm{T}_{0}$ plants. In transgenic $M$. truncatula plants the staining pattern was identical to that seen in alfalfa. Strong staining was seen in emerging roots and nodules, and in root tips. In mature nodules, staining was most prominent in the distal region of the symbiotic zone, invasion zone, and meristem (Fig. 7F). In leaves, GUS activity was found in vascular tissues. In tobacco plants, GUS staining was much less intense than in alfalfa or $M$. truncatula. Staining was observed in root meristems (Fig. 7H) and intermittently in the cortex and vascular tissue. The apical meristems were also

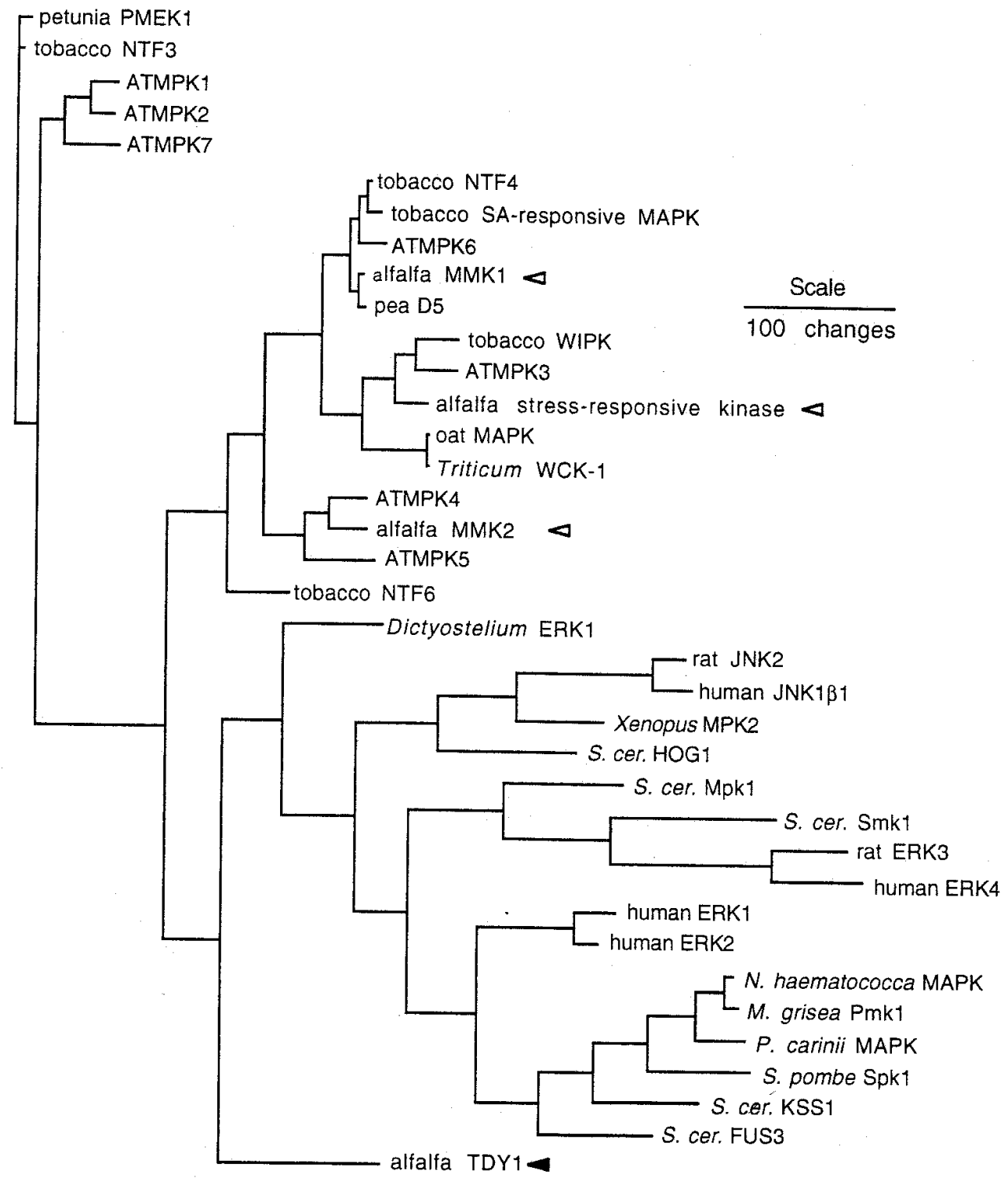

Fig. 4. Phylogenetic analysis of 37 mitogen-activated protein (MAP) kinase amino acid sequences. Sequences were first aligned and trimmed to the positions indicated in Figure 3. TDY1 is indicated with a filled arrowhead; other MAP kinases occurring in alfalfa are indicated with open arrowheads. 


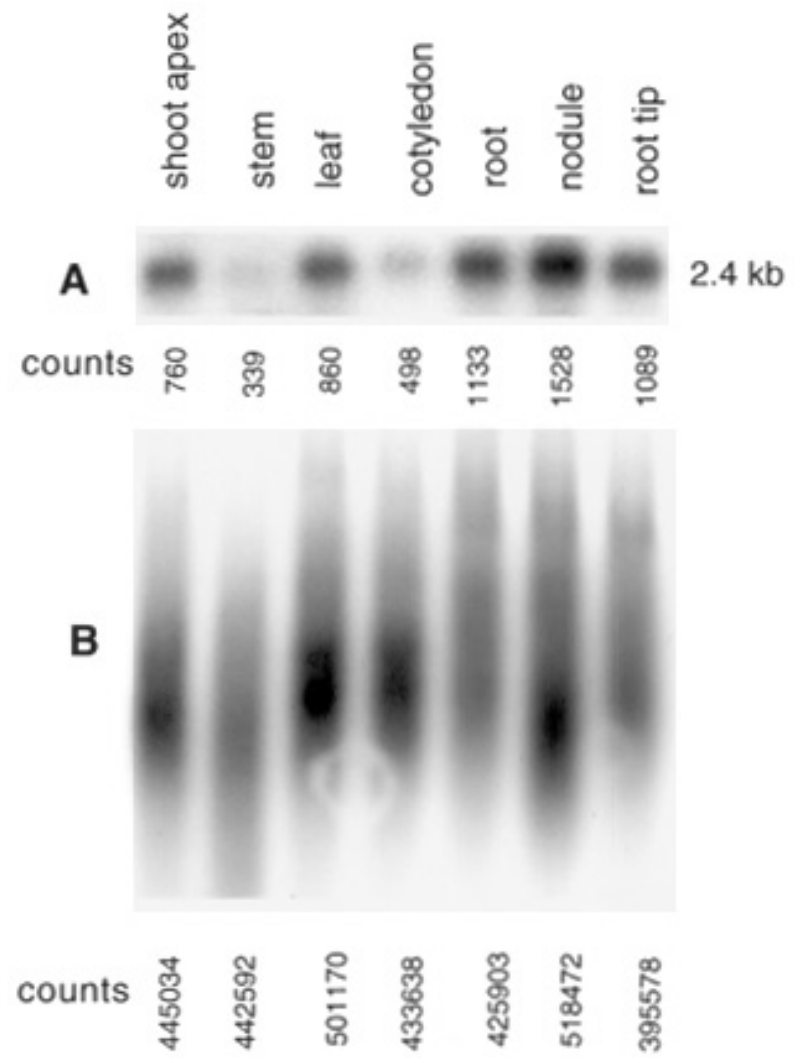

Fig. 5. TDY1 expression patterns in different alfalfa organs. A, Poly(A) ${ }^{+}$ RNA (2 $\mu \mathrm{g}$ per lane) probed with the 1.6-kbp SstI fragment of cDNA mk8. B, The same blot as in A, stripped and probed with ${ }^{32} \mathrm{P}$-labeled poly $(\mathrm{U})$ oligomers. The number of counts registered during a radioanalytic scan is reported below the corresponding lane. positive for GUS activity (Fig. 7I). No constitutive or woundinduced GUS expression was observed in tobacco leaves or stems.

Qualitatively and quantitatively, the transcriptional GUS fusion, pB120, was far less effective at directing GUS expression throughout alfalfa plants. To quantify this difference, and to compare the GUS activities between different organs, we used the in vitro fluorometric assay with 4-methylumbelliferyl $\beta$-D-glucuronic acid (MUG) as the substrate to determine GUS activity in different tissues of representative plants carrying the two constructs. Table 1 summarizes these results.

Table 1. $\beta$-Glucuronidase (GUS) activity in organs of transgenic alfalfa with the TDY1 $5^{\prime}$ flanking region-GUS transcriptional (pB120) and a translational (pB125) fusions

\begin{tabular}{|c|c|c|c|c|c|}
\hline \multirow[b]{2}{*}{ Genotype } & \multicolumn{5}{|c|}{ 4-methyl umbelliferone $(\mathrm{pmol}) / \mathrm{min} / \mathrm{mg}$ of protein } \\
\hline & Apex & Internode & Leaf & Root & Nodule \\
\hline \multicolumn{6}{|l|}{ pB120 } \\
\hline $\mathrm{c} 21$ & 539 & 244 & 320 & 481 & 284 \\
\hline c1234 & 158 & 0 & 166 & 1051 & 241 \\
\hline c2326 & 575 & 784 & 502 & 737 & 309 \\
\hline c1822 & 328 & 694 & 80 & 629 & 619 \\
\hline c1828 & 230 & 335 & 286 & 1,329 & 471 \\
\hline Mean & 366 & 411 & 271 & 845 & 385 \\
\hline \multicolumn{6}{|l|}{ pB125 } \\
\hline c124 & 3,844 & 3,958 & 2,074 & 6,630 & 2,521 \\
\hline $\mathrm{c} 1123$ & 1,183 & 2,007 & 1,159 & 2,498 & 1,140 \\
\hline c239 & 2,940 & 3,051 & 1,530 & 2,815 & 1,752 \\
\hline c2120 & 5,268 & 10,394 & 3,413 & 9,535 & 3,099 \\
\hline c519 & 1,370 & 2,033 & 1,710 & 3,342 & 1,310 \\
\hline Mean & 2,921 & 4,288 & 1,977 & 4,964 & 1,964 \\
\hline+ control $^{\mathrm{a}}$ & 17,162 & 50,008 & 10,536 & 3,590 & 2,451 \\
\hline - control ${ }^{\mathrm{b}}$ & 21 & 17 & 0 & 135 & 161 \\
\hline
\end{tabular}

a Plant containing a cauliflower mosaic virus 35S-GUS gene.

${ }^{\mathrm{b}}$ Regenerated plant containing no transgene.

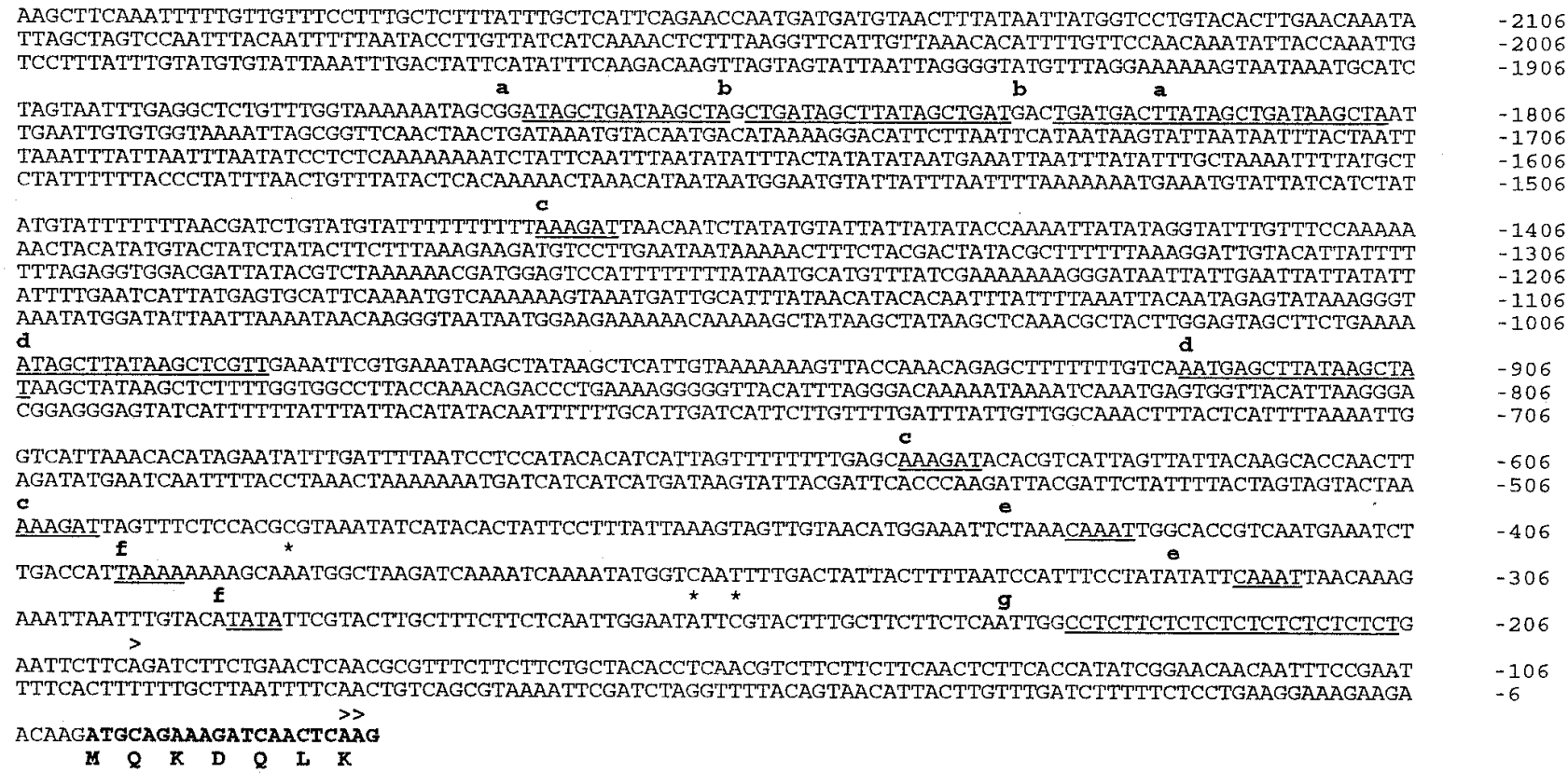

Fig. 6. Sequence of the TDY1 5' flanking region. cDNA beginnings are indicated with stars above the sequence. Underlined sequences: a and b, a pair of nested, partially overlapping direct repeats; $c$, the three occurrences of the AAAGAT motif; d, a pair of inverted repeats; e, CAAT-like motifs; f, TATAlike motifs; g, a polypyrimidine stretch within the $5^{\prime}$ nontranslated region. Location of the transcriptional fusion to the $\beta$-glucuronidase (GUS) reporter gene, pB120, is indicated with a single arrow; the translational fusion, pB125, including seven amino acids of TDY1, is indicated with a double arrow. 
The five plants selected from each of the two groups of transformants (pB120 and pB125) were selected on the basis of their reproducible staining patterns. As positive and negative controls for GUS activity, an otherwise isogenic plant carrying the GUS reporter gene driven by the cauliflower mosaic virus 35S (CaMV 35S) promoter and a plant regenerated from tissue culture with no reporter gene were also assayed. Values reported are the average of activities in duplicate samples. The assay was repeated at a later time with a separate set of cuttings from the same plants with similar results. In all organs examined, GUS activity was higher in plants transformed with the translational fusion $(\mathrm{pB} 125)$ than in plants transformed with the transcriptional fusion (pB120). In roots and nodules there was roughly a fivefold difference in activity between samples from pB120- and pB125-containing plants, while in other organs the difference ranged from seven- to 10 -fold. The actual differences in nodules may be greater as the background activity detected in the nodules of the negative control plant suggests that not all the 4-methyl umbelliferene produced is a result of GUS activity.

\section{DISCUSSION}

With increasing frequency, MAP kinases are being found to have significant roles in the transduction of signals in plants, particularly those signals relating to wounding and stress (Hirt 1997). We have isolated and characterized an alfalfa gene, $T D Y 1$, and its putative promoter region, that appears to encode a novel MAP kinase homolog with enhanced expression in root nodules and root tips. Although cDNAs for MAP kinase genes have been isolated previously from alfalfa and shown to be expressed in roots and stems (Jonak et al. 1993) and upon wounding of leaves (Bögre et al. 1997), this is the first investigation into the occurrence of a MAP kinase in legume root nodules. The gene encompassing the corresponding cDNA sequences spans approximately $4.8 \mathrm{kbp}$, and appears to have 10 exons interrupted by introns ranging in length from 111 to 899 bases. The locations of introns were not comparable to those reported for Schizosaccharomyces pombe (Toda et al. 1996) or Magnaporthe grisea (Xu and Hamer 1996) MAP kinase genes, and many MAP kinase genes reported from fungi or protists appear to be without introns (Courchesne et al. 1989; Toda et al. 1991; Torres et al. 1991; Gaskins et al. 1994). High-stringency blot analysis of alfalfa genomic DNA probed with an internal cDNA fragment (Fig. 2) revealed multiple signals in each lane, suggesting either a high degree of restriction site polymorphism in the genome in or near the TDY1 locus, or alternatively that $T D Y 1$ is part of a family of related genes.

The protein encoded by the TDY1 gene (Fig. 3) is 608 amino acids in length with a predicted molecular mass of 68.9 $\mathrm{kDa}$, significantly larger than other MAP kinase homologs from plants (Bögre et al. 1997). In addition to the 11 subdomains conserved among eukaryotic serine-threonine protein kinases (Hanks and Hunter 1995), the TDY1 protein has an extended carboxyl-terminal domain of approximately 230 amino acids. This region shows significant similarity to a single protein; a partial sequence of a putative MAP kinase homolog from the seedless vascular plant, Selaginella lepidophylla (GenBank accession no. U96717). The carboxylterminal tail of TDY1 is predicted to end in a membrane- spanning $\alpha$-helical structure, potentially anchoring the protein to a membrane. This could suggest a specialized function for TDY1 at the cell membrane or in association with an organelle. Currently, most MAP kinases appear to be soluble proteins, and it has been demonstrated that some forms migrate from the cytoplasm to the nucleus (Chen et al. 1992) or to the cell membrane (Gonzalez et al. 1992) concomitantly with activation.

Adding to the novelty of the TDY1 protein is that the putative regulatory tripeptide motif, the site of activating phosphorylation immediately adjacent to the kinase catalytic domain, occurs as Thr-Asp-Tyr (TDY), as opposed to the Thr-Glu-Tyr (TEY) motif found in all other plant MAP kinases to date. This difference is profound for two reasons. First, it is recognized that multiple forms of MAP kinase can occur within the same cell, and that these different forms transduce distinct signals (Levin and Errede 1995). Seven distinct MAP kinase transcripts have been described in Arabidopsis alone (Mizoguchi et al. 1993, 1994). The maintenance of signal integrity and prevention of cross-talk between signal transduction pathways appear problematic when the kinases involved are very closely related at the molecular level. The assistance of accessory proteins has been demonstrated in yeast models (Elion et al. 1990). It could be, however, that substrate recognition between MAP kinase and its activating kinase is dependent upon the identity of particular regulatory site residues, and that the substituted Asp is an important recognition determinant. Second, many successful attempts to find plant MAP kinase homologs have depended on the conservation of the TEY regulatory motif (Wilson et al. 1993; DecroocqFerrant et al. 1995; Jonak et al. 1995, 1996). As a consequence, however, we may have at present only a narrow view of the whole range of the MAP kinase family of proteins in plants. It will be informative to ascertain whether the complete sequence of the S. lepidophylla MAP kinase homolog, having a carboxyl-terminal tail similar to TDY1, also has a comparable regulatory site.

Phylogenetic analysis of $T D Y 1$, illustrated in Figure 4, further emphasizes its distinctness among plant MAP kinases. All reported plant homologs, with the exception of TDYl, cluster in two related groups. Within the larger group, MAP kinases with similar functions, for example the woundinducible tobacco WIPK, tobacco salicylic acid-responsive MAP kinase, and alfalfa stress-responsive kinase, are closely related (Seo et al. 1995; Bögre et al. 1997). TDY1, by contrast, shares a higher amino acid identity with the $D$. discoideum ERK1 protein (Gaskins et al. 1994). Ferrell (1996) performed a phylogenetic analysis of 42 MAP kinases, including several plant homologs. The results of the two analyses differ in that the plant MAP kinases occur as outgroups in our analysis, distinct from the enzymes characterized in fungi, metazoans, and protoctista. In Ferrell's analysis, the TEY MAP kinase subfamily consisted of MAP kinases from the four eukaryotic kingdoms. Other MAP kinase subfamilies defined by Ferrell are largely conserved in our analysis. Differences between the two phylogenetic analyses are most likely due to differences in the computational algorithm used, and to differences in sequence editing and alignments prior to analysis. Our alignment included 13 more amino acids at the amino-terminal end, a region in which plant MAP kinases share a high degree of amino acid identity. More plant 
sequences will need to be added to the analysis before it can be concluded whether TDY1 and potential TDY1-like proteins emerged prior to the divergence of plants and protists, and whether we could expect to find these proteins among fungi and metazoans.

Expression of TDY1 occurred in all plant organs tested (Fig. $5)$, with high expression in sites with proliferating cells, including root nodules, root tips, and shoot apices. Jonak et al. (1993) showed that the alfalfa MMK1 transcript was expressed at a higher level during the $\mathrm{S}$ and $\mathrm{G} 2$ phases of the cell cycle, and Devitt and Stafstrom (1995) reported the accumulation of MAP kinase transcripts in rapidly proliferating cells of pea axillary buds, though not associated with any particular phase of the cell cycle. Based on our promoter-GUS data, it is likely that the prominent TDY1 message in roots without tips is associated with nascent root tips and nodules that have not yet emerged from the root. Moreover, the detection of TDY1 message in leaves, and in both stems and cotyledons to a lesser degree, indicates that the gene is not associated exclusively with mitosis.

The putative promoter region, illustrated in Figure 6, contained conspicuous repeated elements, both tandem and inverted, that may play a role in promoter function and transcriptional regulation. Inverted repeats, in conjunction with conserved AAAGAT and CTCTT "nod box" motifs, have been demonstrated to be essential for enhanced expression of some nodulin genes in legumes (Jørgensen et al. 1991). The occurrence of the AAAGAT motif in the TDY1 promoter may or may not be of consequence to its expression in alfalfa nodules. The promoter region upstream of the $5^{\prime}$-most cDNA sequence includes TATA and CAAT boxlike motifs found in many eukaryotic genes. However, these motifs also occur within the $5^{\prime}$ nontranslated region of the longest cDNA. This leads us to speculate that the $T D Y 1$ gene may have more than one transcriptional start site although the small size differences precluded distinguishing the transcripts on RNA blots. Multiple transcriptional start sites are not unprecedented among MAP kinase genes. In fact, the closest phylogenetic relative of $T D Y 1$, the gene encoding $D$. discoideum ERK1, is transcribed differentially from two start sites, resulting in transcripts that differ in size by nearly $1 \mathrm{~kb}$ (Gaskins et al. 1994). The 5' nontranslated region of all TDY1 cDNAs contains a striking $(\mathrm{CT})_{9}$ polypyrimidine stretch, which is also found in the $5^{\prime}$ nontranslated region of the alfalfa $M M K 2$ cDNA (Jonak et al. 1995). The role of MMK2 in plants is not known, though it has successfully been used to complement the yeast MPK1deficient lytic phenotype.

Fusion of the 1.8-kbp $5^{\prime}$ flanking region of $T D Y 1$ to the GUS reporter gene permitted further analysis of TDY1 expression patterns. The staining patterns of the majority of plants transformed with the TDY1-GUS fusions are consistent with the RNA blot analysis and show that TDY1 is expressed dif-
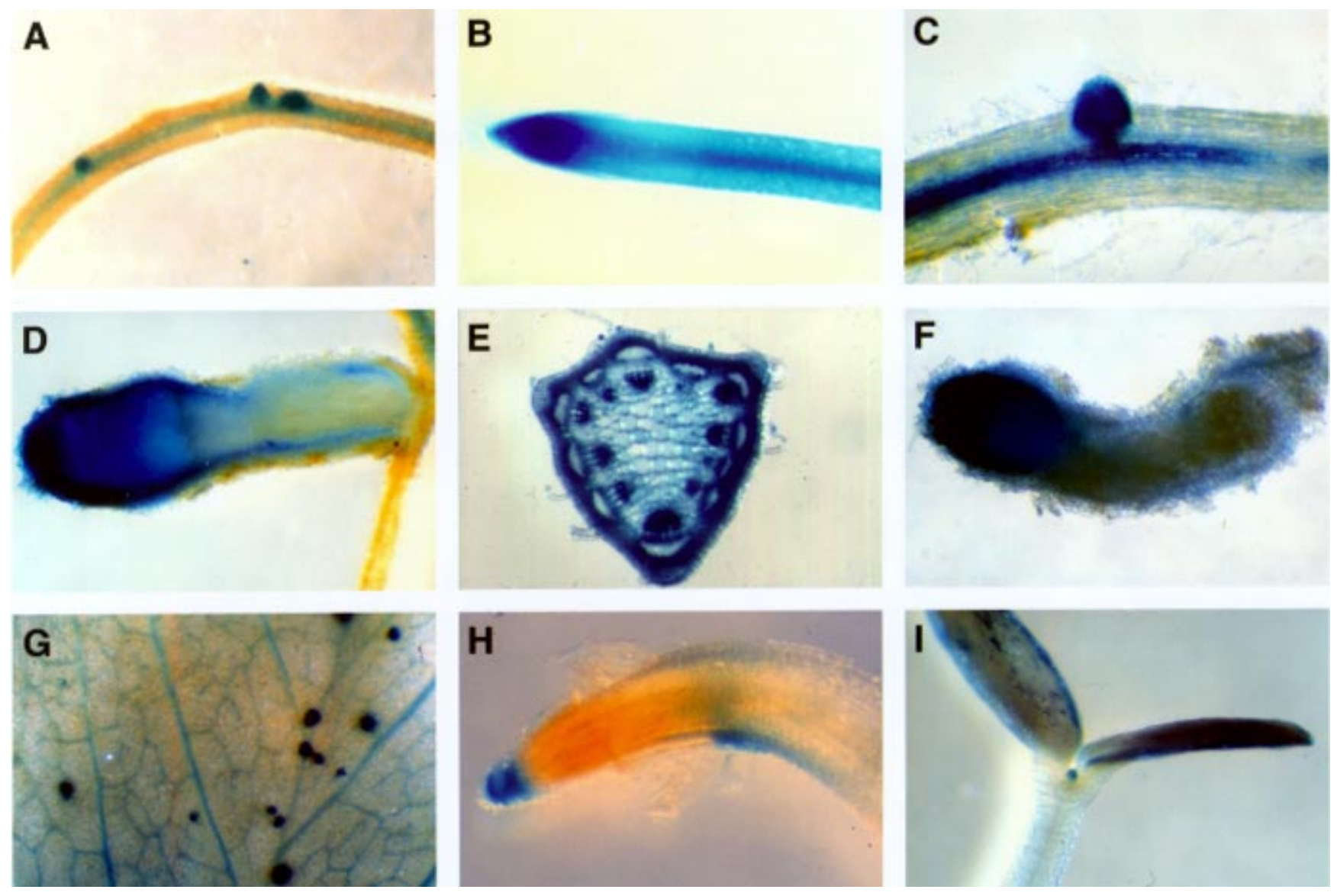

Fig. 7. Histochemical localization of $\beta$-glucuronidase (GUS) activity. A, Alfalfa root with incipient lateral roots (left and center) and nodule (right). B, Alfalfa root tip. C, Emerging alfalfa root nodule. D, Mature alfalfa nodule. E, Cross section of young alfalfa stem. F, Mature Medicago truncatula nodule. G, Alfalfa leaf 4 days after inoculation with Phoma medicaginis. H, Tobacco root tip. I, Tobacco apical meristem. 
ferentially in alfalfa (Fig. 7). A striking pattern of expression occurs in root and nodule tips, which can be distinguished at very early stages of development by the intense staining of meristematic cells (Fig. 7A). In situ hybridization data confirm that $T D Y 1$ transcripts are detectable in the meristems of young nodules not yet emerged from the root (G. B. Trepp and C. P. Vance, unpublished). GUS expression was also prominent in meristems of mature nodules. Recognizing that $3^{\prime}$ sequences and intron sequences may impact gene expression, as well as potential artifacts of the GUS reporter gene system, the data from RNA blotting, X-gluc staining, and in situ hybridization support a role of TDY1 in the development of the symbiotic association between alfalfa and the microsymbiont Sinorhizobium meliloti, a role in nodule initiation and nodule maintenance. TDY1 may also play a role in the interactions with other microbes and in other developmental processes. Strong staining was observed in specific stem tissues (Fig. 7E) and high GUS enzyme activity was measured in stem internodes (Table 1) although limited TDY1 message was detected in alfalfa stems. This difference may reflect a difference in the stability of the GUS mRNA compared with TDY1 mRNA in vascular tissues or may be due to accumulation in the vascular tissue of GUS protein synthesized in meristematic tissues. Measurements of GUS activity (Table 1) also support promoter activity in meristematic and non-meristematic tissues. However, values obtained from different organs cannot be directly compared because they are based on the amount of protein in the samples, which differs dramatically between organs. The difference between the expression of the transcriptional and translational promoter-GUS fusions may be the result of the disruption of a transcriptional regulatory element; conversely, the differences might stem from an alteration in the context of the translational start codon. Identical patterns of GUS expression were observed in transgenic $M$. truncatula and alfalfa containing the promoter-GUS fusions. This is not unexpected, as the two species are closely related. Interestingly, root and shoot meristematic cells in transgenic tobacco plants also had GUS activity, suggesting conservation of transcription factors involved in cell division between Medicago and Nicotiana spp.

The TDY1 promoter appears to be induced both by mechanical wounding and by wounds caused by pathogen invasion. Previous studies have shown that phosphorylation of MAP kinase homologs occurs in plants minutes after wounding and that this activation is accompanied by subsequent accumulation of the corresponding mRNAs (Seo et al. 1995; Bögre et al. 1997). Rapid activation of MAP kinase homologs has also been demonstrated in cell cultures after treatment with fungal elicitors (Suzuki and Shinshi 1995; Ligterink et al. 1997) and salicylic acid (Zhang and Klessig 1997), an endogenous signal that activates a number of plant defense responses. Fungal elicitor treatment also results in rapid increases in MAP kinase gene transcription (Ligterink et al. 1997). Although it is not known if TDY1 is activated by wounding or pathogen invasion, the positive GUS staining in alfalfa leaf cells surrounding wounds and pathogen infection sites does suggest that TDYl gene expression is induced and that the protein is involved in a signal cascade in alfalfa plants responding to these stresses. With the reporting of more plant MAP kinase genomic sequences, and further investigation into the possible functions of putative promoter elements may come a better understanding of the regulation and role of TDY1 in the cells where it is expressed.

\section{MATERIALS AND METHODS}

\section{RT-PCR and cloning of a product resembling a MAP kinase.}

Alfalfa (Medicago sativa) leaf poly(A) ${ }^{+}$RNA $(1 \mu \mathrm{g})$ was heated to $70^{\circ} \mathrm{C}$ for $10 \mathrm{~min}$, then chilled on ice. The RNA was reverse-transcribed in a $25-\mu$ reaction containing $1 \times \mathrm{RT}$ buffer (BRL, Grand Island, NY), $25 \mathrm{mM}$ dNTPs, $1 \mu \mathrm{g}$ of oligo-dT (15-mer), 40 U of RNAsin (Promega, Madison, WI), and $200 \mathrm{U}$ of MMLV reverse transcriptase (BRL) for $1 \mathrm{~h}$ at $37^{\circ} \mathrm{C}$. The reaction was then diluted to $100 \mu \mathrm{l}$ with water and heated to $70^{\circ} \mathrm{C}$ for $15 \mathrm{~min}$. The PCR mixture contained $5 \mu \mathrm{l}$ of first-strand cDNA, $1 \times$ Taq buffer (Boehringer Mannheim, Indianapolis, IN), $2.5 \mathrm{mM} \mathrm{MgCl} 2,200 \mathrm{mM}$ dNTPs, 25 pmol of each primer (5'-GA(A/G)GG(N)GT(N)GC(N)ATGGA-3' and $\left.5^{\prime}-\mathrm{TC}(\mathrm{N}) \mathrm{CC}(\mathrm{N}) \mathrm{GG}(\mathrm{N}) \mathrm{A}(\mathrm{A} / \mathrm{G}) \mathrm{CAT}(\mathrm{N}) \mathrm{GT}-3^{\prime}\right)$, and $2.5 \mathrm{U}$ of Taq DNA polymerase (Boehringer Mannheim). The PCR cycle was $94^{\circ} \mathrm{C}$ for $1 \mathrm{~min}, 42^{\circ} \mathrm{C}$ for $30 \mathrm{~s}$, and $72^{\circ} \mathrm{C}$ for $1 \mathrm{~min}$, for 35 cycles. A DNA band of the approximate expected size of 885 bp was purified from an agarose gel with Geneclean (Bio101, Vista, CA), and cloned into pCR1000 (Invitrogen, San Diego, CA). Two recombinant plasmids containing inserts of slightly different size were obtained and end-sequenced with T7 and T3 primers. One clone shared significant sequence identity with eukaryotic MAP kinases.

\section{Isolation and sequencing of alfalfa nodule cDNA and genomic clones.}

The cloned PCR product was used to prepare a ${ }^{32} \mathrm{P}$-labeled probe with a Decaprime random priming kit (Ambion, Austin, TX) for screening recombinant phage from a cDNA library prepared from alfalfa root nodule mRNA (Gregerson et al. 1993). Recombinant phage $\lambda$ DNA from hybridizing plaques was prepared by the method of Grossberger (1987), and digested with NotI and SalI to release the inserts. Approximately $6 \times 10^{5}$ plaques were screened, and three clones 2.2 $\mathrm{kbp}$ in length or longer were recovered that matched the nucleotide sequence of the PCR product. These cDNAs, named $\mathrm{mk} 1, \mathrm{mk} 6$, and $\mathrm{mk} 8$, were cloned into the Bluescript $\mathrm{SK}^{+}$ vector (Stratagene, La Jolla, CA). Basic molecular cloning techniques were essentially as described by Sambrook et al. (1989). Probes generated with an internal SstI restriction fragment of the mk8 cDNA clone were used to screen approximately $4.5 \times 10^{5}$ plaques of an alfalfa cv. Saranac genomic library (Gregerson et al. 1994) for the corresponding gene. After three rounds of screening, a single recombinant phage was isolated, G8, having an insert size estimated at approximately $20 \mathrm{kbp}$. DNA gel blot analysis of restriction endonuclease-digested G8 DNA suggested that the insert included the entire gene, as different restriction fragments hybridized to probes specific to the $5^{\prime}$ and $3^{\prime}$ ends of the cDNAs. Two fragments of the insert were subcloned into pBluescript $\mathrm{KS}^{+}$; a 5-kbp SstI fragment (subclone $\mathrm{pS1}$ ) comprising the $5^{\prime}$ end of the gene and the upstream adjacent region, and a 5.3-kbp EcoRI fragment (subclone pG81) containing the entire coding region and $3^{\prime}$ nontranslated region up to and beyond the polyadenylation site of the cDNAs. An internal HindIII-EcoRI fragment of pS1 (pSIRID3, $2 \mathrm{kbp}$ ) was 
cloned for sequencing and promoter-GUS reporter gene fusion construction. Both strands of the cDNA clone mk8 and one strand of the genomic clone pSIRID3 were sequenced from nested deletions (Henikoff 1987) with Sequenase 2.0 (US Biochemical, Cleveland, $\mathrm{OH}$ ). Subsequent sequencing of cDNA and genomic clones was performed by automated fluorescence sequencing (Advanced Genetic Analysis Center, St. Paul, MN) with internal oligonucleotide primers. Sequence analysis was performed with the Genetics Computer Group software package (Madison, WI).

\section{Genomic DNA isolation and gel blot analysis.}

Genomic DNA for gel blot analysis was isolated from alfalfa cv. Saranac leaves by the protocol described by Shure et al. (1983). Restriction endonuclease-digested DNA was separated by electrophoresis in a $0.8 \%$ agarose gel and blotted to Immobilon-N membrane (Millipore, Bedford, MA) following depurination, denaturation, and neutralization as described by Gregerson et al. (1993). Conditions for hybridization to ${ }^{32} \mathrm{P}$ labeled probes were as described by Gregerson et al. (1993).

\section{Phylogenetic analysis of MAP kinases.}

A phylogenetic tree of MAP kinases was constructed with the computer program Phylogenetic Analysis Using Parsimony, version 3.1.1 (D. L. Swofford, Illinois Natural History Survey, Champaign, IL). Amino acid sequences for constructing the tree were selected to include representatives of the five MAP kinase subfamilies described by Ferrell (1996). Prior to phylogenetic analysis, the sequences were aligned with the CLUSTAL W 1.7 alignment program (Thompson et al. 1994) and trimmed to remove unique features at the aminoand carboxyl-terminal ends. The sequences used for comparison were rat ERK3 and JNK2 (Boulton et al. 1991; Kyriakis et al. 1994), human ERK1, ERK2, ERK4, and JNK $\beta 1$ (Owaki et al. 1992; Gonzalez et al. 1992; Gupta et al. 1996), Xenopus laevis MPK2 (Rouse et al. 1994), petunia PMEK (Decroocq-Ferrant et al. 1995), tobacco NTF3, NTF4, NTF6, WIPK, and salicylic acid-responsive kinase (Wilson et al. 1993, 1995; Seo et al. 1995; Zhang and Klessig 1997), Arabidopsis ATMPKs 1-7 (Mizoguchi et al. 1993, 1994), alfalfa MMK1, MMK2, and stress-responsive kinase (Duerr et al. 1993; Jonak et al. 1993, 1995, 1996), pea D5 (Stafstrom et al. 1993), oat MAPK (Huttly and Phillips 1995), Triticum aestivum WCK-1 (GenBank accession no. gi3396052), Dictyostelium discoideum ERK1 (Gaskins et al. 1994), Saccharomyces cerevisiae FUS3, KSS1, HOG1, Mpk1, and Smk1 (Courchesne et al. 1989; Elion et al. 1990; Torres et al. 1991; Brewster et al. 1993; Krisak et al. 1994), Schizosaccharomyces pombe Spk1 (Toda et al. 1991), Nectria haematococca MAPK (Li et al. 1997), Magnaporthe grisea PMK1(Xu and Hamer 1996), and Pneumocystis carnii MAPK (GenBank accession no. gi2852373).

\section{RNA isolation and gel blot analysis.}

Total RNA from plant organs was isolated by the method described by Strommer et al. (1993). Poly(A)+ RNA was separated from total RNA with Dynabeads (Dynal, Oslo, Norway) as per the manufacturer's instructions. For RNA blot analysis, RNA was separated by size electrophoretically in a $1.5 \%$ formaldehyde-agarose gel and transferred by blotting to Zeta Probe membrane (BioRad, Hercules, CA). Hybridization with a ${ }^{32} \mathrm{P}$-labeled probe was performed in $50 \%$ deionized formamide at $43^{\circ} \mathrm{C}$ as recommended by the manufacturer. Radioactive counts in hybridizing bands were quantified with an AMBIS radioanalytic scanner (AMBIS Inc., San Diego, CA). Equivalence of poly $(\mathrm{A})^{+}$RNA loading between lanes was tested by subsequently hybridizing the stripped membrane with ${ }^{32} \mathrm{P}$ end-labeled poly(U) oligomers, and determining the counts per lane.

\section{Construction of TDY1 promoter-GUS reporter gene fusions, transformation, and plant culture.}

A transcriptional fusion of the putative TDY1 promoter designated pB120, shown in Figure 6, was constructed by ligating a HindIII-BglII restriction fragment, approximately $1.8 \mathrm{kbp}$ in length, from the pSIRID3 genomic clone into the pBI101.2 vector (Clonetech, Palo Alto, CA) restricted with HindIII and BamHI. This fusion included bases up to position 182 of the longest cDNA clone, and omitted the remaining 203 bases preceding the putative translation start codon. To construct a translational fusion, $\mathrm{pB} 125$, of the same promoter region, a portion of the $5^{\prime}$ nontranslated region of the genomic clone pS1 was amplified through PCR (primers 5'-AGGATC CTTCTTGAGTTGATC-3' and 5'-GTACTTTGCTTCTTCT C-3'), in a 100- $\mu$ l reaction with $1 \mathrm{ng}$ of template DNA, 25 pmol of each primer, 1× Taq buffer (Promega), $2.5 \mathrm{mM}$ $\mathrm{MgCl}_{2}, 70 \mathrm{nM}$ concentrations of each $\mathrm{dNTP}$, and $1 \mathrm{U}$ of $\mathrm{Taq}$ DNA polymerase (Promega), and cycling conditions of $94^{\circ} \mathrm{C}$ for $1 \mathrm{~min}, 45^{\circ} \mathrm{C}$ for $2 \mathrm{~min}$, and $72^{\circ} \mathrm{C}$ for $3 \mathrm{~min}$, for 28 cycles. The amplified fragment was digested with EcoRI and BamHI and inserted into the Bluescript $\mathrm{KS}^{+}$vector (Stratagene). To this insert, the pSIRID3 HindIII-EcoRI fragment was ligated, and the resulting HindIII-BamHI promoter cassette cloned into HindIII-BamHI cut pBI101.2. The PCR amplification added a BamHI site within the putative coding region, and resulted in the addition of seven amino acids of the predicted TDY1 protein, and eight amino acids encoded by the vector, to the amino-terminal end of the GUS protein. The integrity of the genomic amplification product and its orientation in the expression vector were confirmed by sequencing. The constructs were electroporated into Agrobacterium tumefaciens LBA4404 (Ooms et al. 1982).

Transgenic Medicago sativa cv. Regen SY plants were generated essentially as described by Austin et al. (1995). Rooted plantlets were transplanted first to a vermiculite:sand mixture $(1: 1, \mathrm{vol} / \mathrm{vol})$ and subsequently to sand in pots in a glasshouse, and inoculated with the Sinorhizobium meliloti strain 102F51. Presence of the transgene was determined by staining plant organs with X-gluc (Jefferson 1987) with 10\% methanol added to the buffer solution. Green tissues were cleared with $70 \%$ ethanol after staining. Plants testing positive for the GUS reporter gene were propagated clonally through cuttings. Glasshouse materials were maintained in sand supplemented with $\mathrm{K}$, P, and lime, and grown under Na-vapor lamps to provide a 16-h day length. GUS activity was determined essentially as described by Jefferson (1987) with MUG as a substrate. Enzyme activity was measured with a TKO-100 Fluorometer (Hoeffer Scientific, San Francisco, CA). Protein concentration was determined by the BioRad Protein Assay (BioRad Laboratories, Hercules, CA).

For wounding and pathogen inoculation, leaves of alfalfa plants were excised and placed in moist chambers. Leaflets 
were wounded by crushing across the midvein with a pair of hemostats. Leaves were inoculated by spraying a suspension of Phoma medicaginis conidiospores at $10^{6}$ per $\mathrm{ml}$.

For transformation of $M$. truncatula, leaf pieces from 1month-old aseptically grown plants were inoculated with $A$. tumefaciens LBA4404 carrying the pB125 construct. The transformation protocol was similar to that described by Chabaud et al. (1996) with the following modifications. Plants used were the fourth generation of a highly regenerable line, Jemalong 2HA (Wang et al. 1996). Ticarcillin at $500 \mathrm{mg} / \mathrm{liter}$ was used instead of carbenicillin, where necessary. The 3-daylong washing step in CIM liquid medium was replaced by a 10-min wash in sterile water containing $500 \mathrm{mg}$ of ticarcillin per liter. Transformants were planted into sand:vermiculite $(1: 1 ; \mathrm{vol} / \mathrm{vol})$ and inoculated with $S$. meliloti $102 \mathrm{~F} 51$.

Transgenic tobacco were obtained following the protocol of Horsch et al. (1985).

\section{Image processing.}

Photographic images were captured and composite figures were arranged with Photoshop software (Adobe Systems, Mountain View, CA) on a Macintosh computer and printed with a Fujix Pictography 3000 printer at the University of Minnesota Imaging Center.

\section{ACKNOWLEDGMENTS}

We thank Ray J. Rose, University of Newcastle, for providing seeds of $M$. truncatula Jemalong 2HA-4. This paper is a joint contribution from the Plant Science Research Unit, USDA, Agricultural Research Service, and the Minnesota Agricultural Experiment Station (Paper No. 9912262, Scientific Journal Series). Mention of a trademark, proprietary product, or vendor does not constitute a guarantee or warranty of the product by the USDA, and does not imply its approval to the exclusion of other products and vendors that might also be suitable.

\section{LITERATURE CITED}

Austin, S., Bingham, E. T., Mathews, D. E., Shahan, M. N., Will, J., and Burgess, R. R. 1995. Production and field performance of transgenic alfalfa (Medicago sativa L.) expressing alpha-amylase and manganese-dependent lignin peroxidase. Euphytica 85:381-393.

Bögre, L., Calderini, O., Binarova, P., Mattauch, M., Till, S., Kiegerl, S., Jonak, C., Pollaschek, C., Barker, P., Huskisson, N. S., Hirt, H., and Heberle-Bors, E. 1999. A MAP kinase is activated late in plant mitosis and becomes localized to the plane of cell division. Plant Cell 11: 101-114.

Bögre, L., Ligterink, W., Meskiene, I., Barker, P. J., Heberle-Bors, E., Huskisson, N. S., and Hirt, H. 1997. Wounding induces the rapid and transient activation of a specific MAP kinase pathway. Plant Cell 9: 75-83.

Boulton, T. G., Nye, S. H., Robbins, D. J., Ip, N. Y., Radziejewska, E., Morgenbesser, S. D., DePinho, R. A., Panayotatos, N., Cobb, M. H., and Yancopoulos, G. D. 1991. ERKs: A family of protein-serine/ threonine kinases that are activated and tyrosine phosphorylated in response to insulin and NGF. Cell 65:663-675.

Brewster, J. L., Devaloir, T., Dwyer, N. D., Winter, E., and Gustin, M. C. 1993. An osmosensing signal transduction pathway in yeast. Science 259:1760-1763.

Chabaud, M., Larsonneau, C., Marmouget C., and Huguet, T. 1996. Transformation of barrel medic (Medicago truncatula Gaertn.) by Agrobacterium tumefaciens and regeneration via somatic embryogenesis of transgenic plants with the MtENOD12 nodulin promoter fused to the gus reporter gene. Plant Cell Rep. 15:305-310.

Chen, R.-H., Sarnecki, C., and Blenis, J. 1992. Nuclear localization of erk- and $r s k$-encoded protein kinases. Mol. Cell. Biol. 12:915-927.

Courchesne, W. E., Kunisawa, R., and Thorner, J. W. 1989. A putative protein kinase overcomes pheromone-induced arrest of cell cycling in S. cerevisiae. Cell 58:1107-1119.

Decroocq-Ferrant, V., Decroocq, S., Van Went, J., Schmidt, E., and Kreis, E. 1995. A homologue of the MAP/ERK family of protein kinase genes is expressed in vegetative and in female reproductive organs of Petunia hybrida. Plant Mol. Biol. 27:339-350.

Devitt, M. L., and Stafstrom, J. P. 1995. Cell cycle regulation during growth-dormancy cycles in pea axillary buds. Plant Mol. Biol. 29: 255-265.

Duerr, B., Gawienowski, M., Ropp, T., and Jacobs, T. 1993. MsERK1: A mitogen-activated protein kinase from a flowering plant. Plant Cell 5: 87-96.

Elion, E. A., Grisafi, P. L., and Fink, G. R. 1990. FUS3 encodes a cdc2+/ CDC28-related kinase required for the transition from mitosis into conjugation. Cell 60:649-664.

Ferrell, J. E. 1996. MAP kinases in mitogenesis and development. Curr. Top. Dev. Biol. 33:1-60.

Gaskins, C., Maeda, M., and Firtel, R. A. 1994. Identification and functional analysis of a developmentally regulated extracellular signalregulated kinase gene in Dictyostelium discoideum. Mol. Cell. Biol. 14:6996-7012.

Gonzalez, F. A., Raden, D. L., Rigby, M. R., and Davis, R. J. 1992. Heterogeneous expression of four MAP kinase isoforms in human tissues. FEBS Lett. 304:170-178.

Gregerson, R. G., Miller, S. S., Petrowski, M., Gantt, J. S., and Vance, C. P. 1994. Genomic structure, expression, and evaluation of the alfalfa aspartate aminotransferase genes. Plant Mol. Biol. 25:387-399.

Gregerson, R. G., Miller, S. S., Twary, S. N., Gantt, J. S., and Vance, C. P. 1993. Molecular characterization of NADH-dependent glutamate synthase from alfalfa nodules. Plant Cell 5:215-226.

Grossberger, D. 1987. Minipreps of DNA from bacteriophage lambda. Nucleic Acids Res. 15:6737.

Gupta, S., Barrett, T., Whitmarsh, A. J., Cavanagh, J., Sluss, H. K., Derijard, B., and Davis, R. J. 1996. Selective interaction of JNK protein kinase isoforms with transcription factors. EMBO J. 15:27602770.

Hanks, S. K., and Hunter, T. 1995. The eukaryotic protein kinase superfamily. Pages 7-47 in: The Protein Kinases Facts Book I: ProteinSerine Kinases. G. Hardie and S. Hanks, eds. Academic Press, San Diego, CA.

Henikoff, S. 1987. Unidirectional digestion with exonuclease III in DNA sequence analysis. Methods Enzymol. 155:156-165.

Hirt, H. 1997. Multiple roles of MAP kinases in plant signal transduction. Trends Plant Sci. 2:11-15.

Hofman, K., and Stoffel, W. 1993. A database of membrane spanning protein segments. Biol. Chem. 374:166.

Horsch, R., Fry, J., Hoffman, N., Eichholtz, D., Rogers, S., and Fraley, R. 1985. A simple and general method for transferring genes into plants. Science 227:1229-1231.

Huttly, A. K., and Phillips, A. W. 1995. Gibberellin-regulated expression in oat aleurone cells of two kinases that show homology to MAP kinase and a ribosomal protein kinase. Plant Mol. Biol. 27:1043-1052.

Jefferson, R. A. 1987. Assaying chimeric genes in plants: The GUS gene fusion system. Plant Mol. Biol. Rep. 5:387-405.

Jonak, C., Kiegerl, S., Ligterink, W., Barker, P. J., Huskisson, N. S., and Hirt, H. 1996. Stress signaling in plants: A mitogen-activated protein kinase pathway is activated by cold and drought. Proc. Natl. Acad. Sci. USA 93:11274-11279.

Jonak, C., Kiegerl, S., Lloyd, C., Chan, J., and Hirt, H. 1995. MMK2, a novel alfalfa MAP kinase, specifically complements the yeast MKP1 function. Mol. Gen. Genet. 248:686-694.

Jonak, C., Páy, A., Bögre, L., Hirt, H., and Heberle-Bors, E. 1993. The plant homologue of MAP kinase is expressed in a cell cycledependent and organ-specific manner. Plant J. 3:611-617.

Jørgensen, J.-E., Stougaard, J., and Marcker, K. A. 1991. A twocomponent nodule-specific enhancer in the soybean N23 gene promoter. Plant Cell 3:819-828.

Kneller, D. G., Cohen, F. E., and Langridge, R. 1990. Improvements in protein secondary structure prediction by an enhanced neural network. J. Mol. Biol. 214:171-182.

Knetsch, M. L. W., Wang, M., Snaar-Jagalska, B. E., and HeimovaaraDijkstra, S. 1996. Abscisic acid induces mitogen-activated protein kinase activation in barley aleurone protoplasts. Plant Cell 8:10611067. 
Krisak, L., Strich, R., Winters, R. S., Hall, J. P., Mallory, M. J., Kreitzer, D., Tuan, R. S., and Winter, E. 1994. SMK1, a developmentally regulated MAP kinase is required for spore wall assembly in Saccharomyces cerevisiae. Genes Dev. 8:2151-2161.

Kyriakis, J. M., Banerjee, P., Nikolakaki, E., Dai, T., Rubie, E. A., Ahmad, M. F., Avruch, J., and Woodgett, R. J. 1994. The stress-activated protein kinase subfamily of c-Jun kinases. Nature 369:156-160.

Levin, D. E., and Errede, B. 1995. The proliferation of MAP kinase signaling pathways in yeast. Curr. Opin. Cell. Biol. 7:197-202.

Li, D., Rogers, L., and Kolattududy, P. E. 1997. Cloning and expression of cDNA encoding a mitogen-activated protein kinase from a phytopathogenic filamentous fungus. Gene 195:161-166.

Ligterink, W., Kroj, T., zur Nieden, U., Hirt, H., and Scheel, D. 1997. Receptor-mediated activation of a MAP kinase in pathogen defense of plants. Science 276:2054-2057.

Machida, Y., Nishihama, R., and Kitakura, S. 1997. Progress in studies of plant homologs of mitogen-activated protein (MAP) kinase and potential upstream components in kinase cascades. Crit. Rev. Plant Sci. 16:481-496.

Maniatis, T., Goodbourne, S., and Fischer, J. A. 1987. Regulation of inducible and tissue-specific gene expression. Science 236:1237-1245.

Mizoguchi, T., Gotoh, Y., Nishida, E., Yamaguchi-Shinozaki, K., Hayashida, N., Iwasaki, T., Kamada, H., and Shinozaki, K. 1994. Characterization of two cDNAs that encode MAP kinase homologues in Arabidopsis thaliana and analysis of the possible role of auxin in activating such kinase activities in cultured cells. Plant J. 5:111-122.

Mizoguchi, T., Hayashida, N., Yamaguchi-Shinozaki, K., Kamada, H., and Shinozaki, K. 1993. ATMPKs: A gene family of plant MAP kinases in Arabidopsis thaliana. FEBS Lett. 336:440-444.

Ooms, G., Hooykaas, P. J. J., van Veen, R. J. M., van Beelen, P., Regensburg-Tuïnk, T. J. G., and Schilperoort, R. A. 1982. Octopine Tiplasmid deletion mutants of Agrobacterium tumefaciens with emphasis on the right side of the T-region. Plasmid 7:15-29.

Owaki, H., Makar, R., Boulton, T. G., Cobb, M. H., and Geppert, T. D. 1992. Extracellular signal-regulated kinases in T cells: Characterization of human ERK1 and ERK2 cDNAs. Biochem. Biophys. Res. Commun. 182:1416-1422.

Proudfoot, N. J. 1991. Poly(A) signals. Cell 64:671-674.

Rouse, J., Cohen, P., Trigon, S., Morange, M., Alonso-Llamazares, A., Zamanillo, D., Hunt, T., and Nebreda, A. R. 1994. A novel kinase cascade triggered by stress and heat shock that stimulates MAPKAP kinase- 2 and phosphorylation of the small heat shock proteins. Cell 78:1027-1037.

Sambrook, J., Fritsch, E. F., and Maniatis, T. A. 1989. Molecular Cloning: A Laboratory Manual. 2nd ed. Cold Spring Harbor Laboratory, Cold Spring Harbor, NY

Seo, S., Okamoto, M., Seto, H., Ishizuka, K., Sano, H., and Ohashi, Y. 1995. Tobacco MAP kinase: A possible mediator in wound signal transduction pathways. Science 270:1988-1992.
Shure, M., Wessler, S., and Federoff, N. 1983. Molecular identification and isolation of the Waxy locus in maize. Cell 35:235-242.

Stafstrom, J. P., Altschuler, M. A., and Anderson, D. H. 1993. Molecular cloning and expression of a MAP kinase homologue from pea. Plant Mol. Biol. 22:83-90.

Stougaard, J., Sandal, N. N., Gron, A., Kühle, A., and Marcker, K. A. 1987. $5^{\prime}$ analysis of the soybean leghaemoglobin $l b c 3$ gene: Regulatory elements required for promoter activity and organ specificity. EMBO J. 6:3565-3569.

Strommer, J. N., Gregerson, R. G., and Vayda, M. 1993. Isolation and characterization of plant mRNA. Pages 49-65 in: Methods in Plant Molecular Biology and Biotechnology. B. Glick and J. Thompson, eds. CRC Press Inc., Boca Raton, FL.

Suzuki, K., and Shinshi, H. 1995. Transient activation and tyrosine phosphorylation of a protein kinase in tobacco cells treated with a fungal elicitor. Plant Cell 7:639-674.

Thompson, J. D., Higgins, D. G., and Gibson, T. J. 1994. CLUSTAL W: Improving the sensitivity of progressive multiple sequence alignment through sequence weighting, positions-specific gap penalties and weight matrix choice. Nucleic Acids Res. 22:4673- 4680.

Toda, T., Dhut, S., Superti-Furga, G., Gotoh, Y., Nishida, E., Sugiura, R., and Kuno, T. 1996. The fission yeast pmkl+ gene encodes a novel mitogen-activated protein kinase homolog which regulates cell integrity and functions coordinately with the protein kinase $\mathrm{C}$ pathway. Mol. Cell. Biol. 16:6752-6764

Toda, T., Shimanuki, M., and Yanagida, M. 1991. Fission yeast genes that confer resistance to staurosporine encode an AP-1-like transcription factor and a protein kinase related to the mammalian ERK1/MAP2 and budding yeast FUS3 and KSS1 kinases. Genes Dev. 5:60-73.

Torres, L., Martin, H., Garcia-Saez, M. I., Arroyo, J., Molina, M., Sanchez, M., and Nombela, C. 1991. A protein kinase gene complements the lytic phenotype of Saccharomyces cerevisiae lyt 2 mutants. Mol. Microbiol. 5:2845-2854.

Wang, J. H., Rose, P. R., and Donaldson, B. I. 1996. Agrobacteriummediated transformation and expression of foreign genes in Medicago truncatula. Aust. J. Plant Physiol. 23:265-270.

Wilson, C., Anglmayer, R., Vincente, O., and Heverle-Bors, E. 1995. Molecular cloning, functional expression in Escherichia coli, and characterization of multiple mitogen-activated-protein kinases from tobacco. Eur. J. Biochem. 233:249-257.

Wilson, C., Eller, N., Gartner, A., Vicente, O., and Heberle-Bors, E. 1993. Isolation and characterization of a tobacco cDNA clone encoding a putative MAP kinase. Plant Mol. Biol. 23:543-551.

Xu, J. R., and Hamer, J. E. 1996. MAP kinase and cAMP signaling regulate infection structure formation and pathogenic growth in the rice blast fungus Magnaporthe grisea. Genes Dev. 10:2696-2706.

Zhang, S., and Klessig, D. F. 1997. Salicylic acid activates a 48kilodalton MAP kinase in tobacco. Plant Cell 9:809-824. 